\title{
THE DAILY URINARY EXCRETION OF ESTROGENIC AND ANDRO- GENIC SUBSTANCES BY NORMAL MEN AND WOMEN ${ }^{1}$
}

\author{
By T. F. GALLAGHER, D. H. PETERSON, R. I. DORFMAN, A. T. KENYON AND \\ F. C. $\mathrm{KOCH}$ \\ (From the Departments of Biochemistry and Medicine, The University of Chicago, Chicago)
}

(Received for publication March 15, 1937)

It is well established that normal men and women excrete estrogenic and androgenic substances in the urine. Qualitatively speaking, it is also well established that at least a part of the androgenic activity in men's urine is due to androsterone and dehydro-androsterone $(1,2,3)$, but we do not know the exact chemical nature of the androgenic material in women's urine. Furthermore, we do not know the true chemical nature of the estrogenic substances found in the urine of normal men and non-pregnant normal women. Comparative biological and chemical studies by Dorfman, Gallagher and Koch (4) indicate that the estrogenic activity of men's urine is not theelol but very likely theelin.

Quantitative information on the distribution of these activities in adult human urine is even less satisfactory. In most cases the extractions have been incomplete, and the assays are based on too few animals or have not been properly compared with pure standards. The brief review below reveals the striking extremes reported thus far and the impossibility of interpreting most of the data in terms of common standards of known purity.

Funk and Harrow (5) employed concentrated alcoholic extracts from concentrated human urines and concluded that the urines from men 70 to 80 years of age do not contain enough androgenic material to be detected by the comb-growth method. Siebke (6) reported the daily excretion of 0 to 1 capon unit of androgens in young women's urine and that it requires 2.5 to 10 liters to yield 1 capon unit. He did not acidify the urine, and his extraction probably was very incomplete. Ogata and Ito (7) from studies by chloroform extraction of urine concluded that the excretion in normal man varies with the season. Bühler (8) prepared benzene extracts of the alkaline urine. He reports daily excretions of 0 to 2

1 These investigations were supported in part by a grant from the Rockefeller Foundation. capon units in normal men. His capon unit is approximately equal to 0.75 international androgenic unit or $0.075 \mathrm{mgm}$. of androsterone. Two recent studies give much higher yields on normal individuals. A study by Simpson, de Fremery, and Macbeth (9) by chloroform extraction reports the excretion of 10 to 50 capon units, equivalent to approximately 7 to 35 international capon units per day in normal women, but that the fluctuations bear no relation to menstruation. Kochakian (10) employed a modification of the method of Funk and Harrow (5). He reports the excretion of 19 to 48 international capon units per day in normal men.

There is somewhat better agreement on the daily excretion of estrogenic activity in women, but practically no data on the excretion in men. Siebke (6) first reported 0 to 180 mouse units per liter of women's urine throughout the cycle. From studies on eight normal women he concluded that there is a low excretion previous to and during menstruation. Later Siebke (11) reported 10 to 140 mouse units of estrogenic activity per liter of urine in women with a distinct rise between the 10th to the 15th day of the cycle. Frank (12) reported 20 to 320 mouse units per day with peaks at 12 to 15 days after the onset of menstruation and 4 to 8 days before the next bleeding. Bühler (8) reported 10 to 60 mouse units per day in normal men. Gustavson and Green (13) and Smith and Smith (14) also report two peaks in the excretion of estrogenic activity in women during the menstrual cycle. The former find 0 to 50 rat units per day with peaks at the 9th to 14th day and the 14th to 21st day after menstruation. Smith and Smith (14) record the peaks at 12 to 17 days after menstruation and during menstruation.

In this paper we present our methods of extraction and assay in detail and the results on four normal men and four normal women for 27 to 45 consecutive days. The male urine was collected 
in three-day samples with a few exceptions. The women's urine was collected in two-day periods during the cycle excepting during menstruation when it was collected as one sample. The women were found to be normal individuals by Dr. M. E. Davis of the Department of Obstetrics and Gynecology, University of Chicago.

\section{EXPERIMENTAL}

Methods. The evidence that our extraction of urine is complete is shown by Gallagher, Koch and Dorfman (15) and has also been confirmed repeatedly in our subsequent studies. The quantitative value of the malehormone assay by the comb-growth method on the basis of the characteristic curve found by Gallagher and Koch (16) is also well established as a result of numerous quantitative studies. The estrogenic assay, in our opinion, is by no means as satisfactory because of the greater individual animal variations and the necessary limitation to the use of no more than ten spayed rats for each assay on account of the lack of material for injection.

Extractor. The special features of the extractor are the very rapid distillation of the benzene, the very fine division of the benzene, and the long column of urine through which the benzene rises. The condenser is very efficient because it is cooled by a current of water through the jacket and through the four inner tubes. These special features make the extraction very efficient and rapid. In place of Wood's metal, one may use a 50:50 mixture of lead and tin. The total height of the apparatus is eleven feet.

Extraction of androgenic and estrogenic activities from urine. The 24-hour or larger sample of urine is acidified by the addition of $100 \mathrm{cc}$. concentrated commercial $\mathrm{HCl}$ per liter of urine. After being boiled for 15 minutes under a reflux condenser and cooled, the urine is extracted in the special extractor with benzene until it has been contacted with at least twelve volumes of benzene. (Originally we boiled the urine 1 to 2 hours, but we now recommend 15 minutes because the yield of androgenic material is increased approximately by an average of 66 per cent (17).)

If the amount to be extracted is not greater than the capacity of the extractor (2000 to $2500 \mathrm{cc}$., depending on the extractor), the urine is transferred to the extractor, filling it to the mark 10 inches below the inlet (for smaller samples, water may be added to bring it to the mark), then enough benzene added at the urine inlet just to fill the U-tube connection to the flask. About $500 \mathrm{cc}$. of benzene are transferred to the flask which is connected with the apparatus. The benzene is heated to boiling, but it should be observed that when the benzene first begins to boil vigorously, there is some danger of flooding the condenser. If this happens, the hot plate should be lowered momentarily, then raised again and adjusted to a constant rate of boiling. After the boiling has continued for at least one hour, the rate at which benzene is distilled over is determined by collecting the benzene from the small side-tube at the right-hand side. The rate of distillation should be 100 to $140 \mathrm{cc}$. per minute. The benzene collected in determining the rate should be returned at the urine inlet after closing the side tube. After the rate has been determined, the extraction is continued until at least twelve volumes of benzene per volume of urine have been passed through the urine. In the early part of the extraction, an emulsion may form at the surface of the urine. If this happens, the hot plate under the flask should be lowered for about one-half hour or until the emulsion is broken. If the emulsion persists, a small amount of saturated salt solution should be added at the urine inlet and allowed to stand for another half hour. If this fails, a few cc. of a 3 per cent solution of sodium glycocholate should succeed in breaking the emulsion.

If a continuous flow of urine is being extracted, the rate of introduction of urine at the inlet and the outflow at a constant level at the outlet must be so regulated that the urine is introduced at one-twelfth the rate of distillation of the benzene.

The benzene extract is evaporated to a viscid oil on the water bath or in a flask under diminished pressure to hasten evaporation. If this is attempted on a hot plate, there is danger of overheating. The oil is next dissolved in $50 \mathrm{cc}$. of ether and quantitatively transferred to a 250-cc. separatory funnel with three washings of ether of $15 \mathrm{cc}$. each. The ether solution is then shaken with three changes of $20 \mathrm{cc}$. of a saturated aqueous solution of sodium bicarbonate. The ether layer is quantitatively recovered. The aqueous phase is discarded. If it is not desired to separate the male and female hormones, the ether solution may be evaporated to the viscid oil stage, taken up in 95 per cent alcohol, filtered through paper into a $25-$ or 50 -cc. volumetric flask, and diluted to the mark by washing through the filter with 95 per cent alcohol. Parts of this alcoholic stock solution are used for the assay as indicated under Assay for estrogenic activity below. It is better, however, to separate the androgenic and estrogenic activities before conducting either assay.

Separation of the androgenic and estrogenic hormones. The ether solution is shaken ten times with 50-cc. lots of 10 per cent $\mathrm{NaOH}$ in water, combined, and the $\mathrm{NaOH}$ washings saved. Then the ether layer is washed once by shaking with $15 \mathrm{cc}$. of 10 per cent $\mathrm{H}_{2} \mathrm{SO}_{4}$ and washed again four times with 15-cc. volumes of distilled water. The acid and water washings are discarded. The combined alkaline-aqueous solution contains the estrogenic material; the ether layer retains the androgenic hormone. To recover the estrogenic substances, the alkaline-aqueous solution is acidified with $160 \mathrm{cc} .8 \mathrm{~N} \mathrm{H}_{2} \mathrm{SO}_{4}$, allowed to cool, and tested with litmus to be certain that it is acid. The acidified aqueous solution is extracted with 150-, 100-, 75- and 50-cc. portions of ether. The aqueous acid solution is discarded. The combined ether extracts are shaken four times with 50-cc. portions of water. The ether layer is evaporated on a water or steam bath to a viscid oil. To remove the traces of water, about 15 cc. alcohol are added and the extract re-evaporated on a 


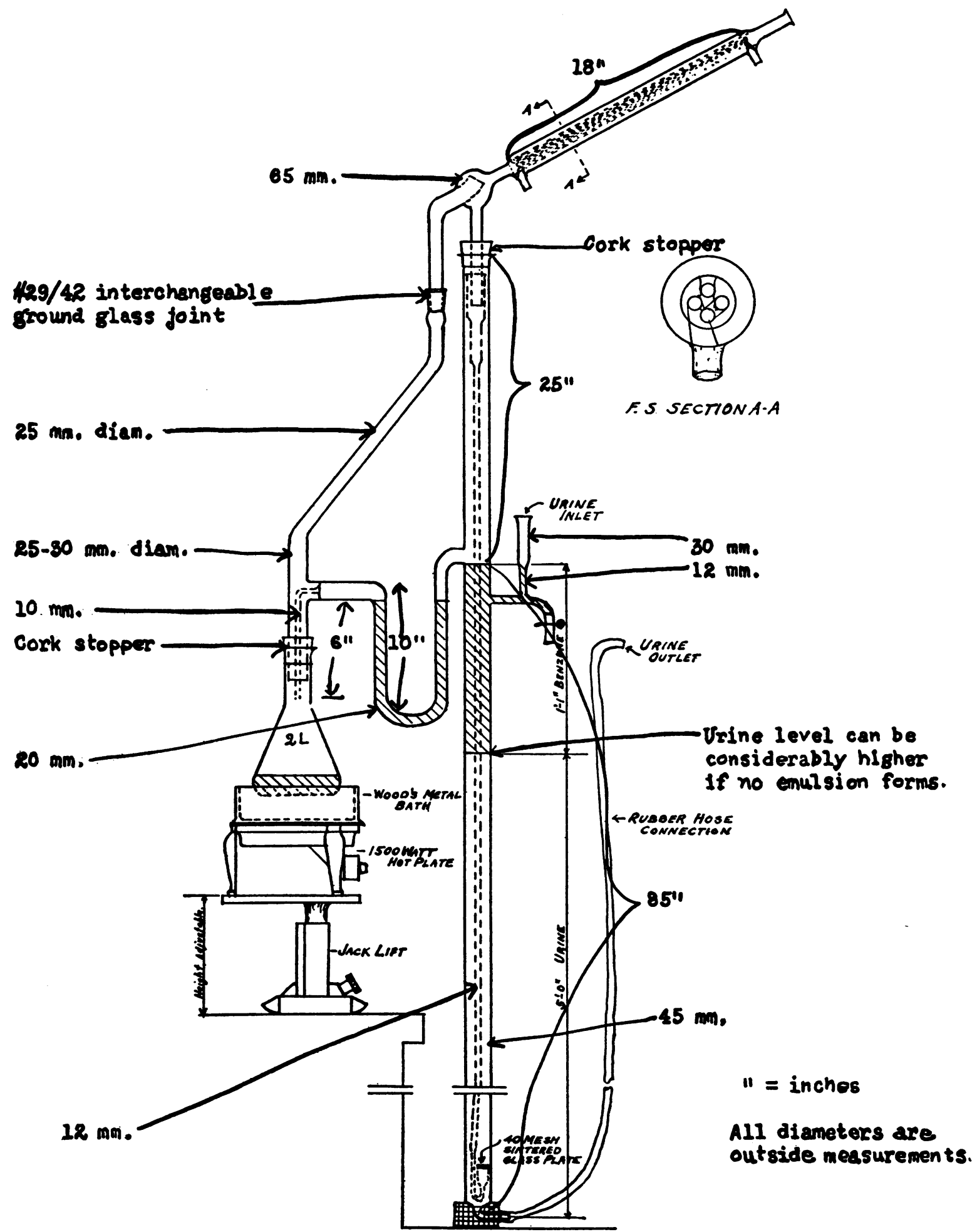

Fig. 1. Continuous Extractor for Sex Hormones from Urine 
hot-water bath under diminished pressure (cautiously, to avoid loss due to foaming). The sample is made up to 25 or $50 \mathrm{cc}$. in a volumetric flask with 95 per cent alcohol. The solution is filtered while making up to volume. This serves as the stock solution for assay purposes. Aliquot parts are added to the desired volume of sesame or olive oil and the mixture heated under diminished pressure by immersion in a water bath until the alcohol is removed.

The ether layer containing the androgenic hormone is likewise evaporated and the residue dissolved in 95 per cent alcohol and made up to volume. A part or the whole may be dissolved in olive oil of desired volume.

Assay for the estrogenic activity. If the adult spayed albino rats have not been used for assay for two weeks previously, they must first be primed with a dose of 0.88 to 2.0 gamma theelin or the equivalent of estrogenic material ten days to two weeks before injection with the unknown preparation. The dose injected is always contained in $0.5 \mathrm{cc}$. of olive oil. Ten such primed rats are injected with 0.88 to 2.0 gamma of the standard theelin preparation and at the same time ten more are injected with the unknown preparation. Vaginal smears are made 42, 46 and 52 hours after the time of injection, examined under low power $(100 \times)$, and the character of each recorded. The test is considered positive when the smear is free from leukocytes and contains aggregates of nonnucleated epithelial cells. From the percentage of animals showing a positive reaction, the concentration of estrogenic units is read from the standard curve of D'Amour and Gustavson (18) in terms of gamma of theelin as compared with the standard run in parallel.

Assay of androgenic activity. The androgenic activity of the alkali-insoluble fraction is determined by the method of Gallagher and Koch (16). Briefly, it consists of injecting seven capons daily for five days with $1 \mathrm{cc}$. each of the unknown in oil. The length and height of the combs are measured on the first and sixth day and the average total growth obtained. A standard containing 100 gamma of androsterone or its equivalent is assayed in parallel with the unknowns using the same number of capons. Since the growth obtained is a function of the initial comb-length, the average initial comblength of the capons receiving the unknown preparations is corrected to the average initial comb-length of those receiving the standard preparation. For each millimeter difference in initial comb-length from the standard, there is a $0.2 \mathrm{~mm}$. difference in total growth obtained on each unknown. Then, according to the curve obtained by Gallagher and Koch (16), the total capon units are determined. In place of the curve, Table I may be found more convenient for the calculation of the unknowns in terms of the standard. The footnote to the table illustrates the method of calculation.

\section{DISCUSSION OF THE RESULTS}

Male urine. The results on the four men are given in Figure 2 and Table II. The irregular
TABLE I

Relation of increase in $L+H$ of capon comb to $1 / 1000 \mathrm{cc}$. of preparation $\theta S H$

(From Gallagher and Koch standard curve, J. Pharmacol. and Exper. Therap., 1936, 55, 111)

\begin{tabular}{|c|c|c|c|c|c|c|c|}
\hline $\begin{array}{l}\text { Comb- } \\
\text { growth } \\
\mathbf{L}+\mathbf{H}\end{array}$ & $\begin{array}{c}\text { OSH } \\
0.001 \\
\text { cc. }\end{array}$ & $\begin{array}{l}\text { Comb- } \\
\text { growth } \\
\mathrm{L}+\mathrm{H}\end{array}$ & $\begin{array}{c}\theta \text { SH } \\
0.001 \\
\text { cc. }\end{array}$ & $\begin{array}{l}\text { Comb- } \\
\text { growth } \\
\mathbf{L}+\mathbf{H}\end{array}$ & $\begin{array}{c}\text { eSH } \\
0.001 \\
\text { cc. }\end{array}$ & $\begin{array}{l}\text { Comb- } \\
\text { growth } \\
\mathrm{L}+\mathrm{H}\end{array}$ & $\begin{array}{c}\theta \mathrm{SH} \\
0.001 \\
\text { cc. }\end{array}$ \\
\hline $\begin{array}{c}m m . \\
0.5 \\
0.6 \\
0.7 \\
0.8 \\
0.9\end{array}$ & $\begin{array}{l}0.30 \\
0.38 \\
0.45 \\
0.51 \\
0.60\end{array}$ & $\begin{array}{l}m m . \\
3.5 \\
3.6 \\
3.7 \\
3.8 \\
3.9\end{array}$ & $\begin{array}{l}4.30 \\
4.51 \\
4.70 \\
4.91 \\
5.11\end{array}$ & $\begin{array}{l}m m . \\
6.5 \\
6.6 \\
6.7 \\
6.8 \\
6.9\end{array}$ & $\begin{array}{l}10.81 \\
11.08 \\
11.30 \\
11.55 \\
11.80\end{array}$ & $\begin{array}{c}m m . \\
9.5 \\
9.6 \\
9.7 \\
9.8 \\
9.9\end{array}$ & $\begin{array}{l}19.55 \\
19.94 \\
20.30 \\
20.70 \\
21.08\end{array}$ \\
\hline $\begin{array}{l}1.0 \\
1.1 \\
1.2 \\
1.3 \\
1.4\end{array}$ & $\begin{array}{l}0.67 \\
0.75 \\
0.85 \\
0.95 \\
1.05\end{array}$ & $\begin{array}{l}4.0 \\
4.1 \\
4.2 \\
4.3 \\
4.4\end{array}$ & $\begin{array}{l}5.31 \\
5.54 \\
5.75 \\
5.95 \\
6.15\end{array}$ & $\begin{array}{l}7.0 \\
7.1 \\
7.2 \\
7.3 \\
7.4\end{array}$ & $\begin{array}{l}12.00 \\
12.28 \\
12.53 \\
12.80 \\
13.05\end{array}$ & $\begin{array}{l}10.0 \\
10.1 \\
10.2 \\
10.3 \\
10.4\end{array}$ & $\begin{array}{l}21.48 \\
21.90 \\
22.30 \\
22.75 \\
23.20\end{array}$ \\
\hline $\begin{array}{l}1.5 \\
1.6 \\
1.7 \\
1.8 \\
1.9\end{array}$ & $\begin{array}{l}1.15 \\
1.27 \\
1.40 \\
1.51 \\
1.61\end{array}$ & $\begin{array}{l}4.5 \\
4.6 \\
4.7 \\
4.8 \\
4.9\end{array}$ & $\begin{array}{l}6.40 \\
6.60 \\
6.80 \\
7.00 \\
7.22\end{array}$ & $\begin{array}{l}7.5 \\
7.6 \\
7.7 \\
7.8 \\
7.9\end{array}$ & $\begin{array}{l}13.33 \\
13.60 \\
13.88 \\
14.14 \\
14.41\end{array}$ & $\begin{array}{l}10.5 \\
10.6 \\
10.7 \\
10.8 \\
10.9\end{array}$ & $\begin{array}{l}23.65 \\
24.12 \\
24.60 \\
25.10 \\
25.64\end{array}$ \\
\hline $\begin{array}{l}2.0 \\
2.1 \\
2.2 \\
2.3 \\
2.4\end{array}$ & $\begin{array}{l}1.74 \\
1.87 \\
2.01 \\
2.20 \\
2.31\end{array}$ & $\begin{array}{l}\mathbf{5 . 0} \\
\mathbf{5 . 1} \\
5.2 \\
\mathbf{5 . 3} \\
\mathbf{5 . 4}\end{array}$ & $\begin{array}{l}7.45 \\
7.78 \\
7.90 \\
8.10 \\
8.31\end{array}$ & $\begin{array}{l}8.0 \\
8.1 \\
8.2 \\
8.3 \\
8.4\end{array}$ & $\begin{array}{l}14.70 \\
15.00 \\
15.30 \\
15.60 \\
15.90\end{array}$ & $\begin{array}{l}11.0 \\
11.1 \\
11.2 \\
11.3 \\
11.4\end{array}$ & $\begin{array}{l}26.15 \\
26.68 \\
27.25 \\
27.81 \\
28.40\end{array}$ \\
\hline $\begin{array}{l}2.5 \\
2.6 \\
2.7 \\
2.8 \\
2.9\end{array}$ & $\begin{array}{l}2.49 \\
2.64 \\
2.80 \\
3.00 \\
3.15\end{array}$ & $\begin{array}{l}\mathbf{5 . 5} \\
\mathbf{5 . 6} \\
\mathbf{5 . 7} \\
\mathbf{5 . 8} \\
\mathbf{5 . 9}\end{array}$ & $\begin{array}{l}8.54 \\
8.76 \\
8.98 \\
9.20 \\
9.41\end{array}$ & $\begin{array}{l}8.5 \\
8.6 \\
8.7 \\
8.8 \\
8.9\end{array}$ & $\begin{array}{l}16.21 \\
16.54 \\
16.85 \\
17.18 \\
17.50\end{array}$ & $\begin{array}{l}11.5 \\
11.6 \\
11.7 \\
11.8 \\
11.9\end{array}$ & $\begin{array}{l}29.02 \\
29.68 \\
30.35 \\
31.05 \\
31.75\end{array}$ \\
\hline $\begin{array}{l}3.0 \\
3.1 \\
3.2 \\
3.3 \\
3.4\end{array}$ & $\begin{array}{l}3.35 \\
3.54 \\
3.74 \\
3.95 \\
4.11\end{array}$ & $\begin{array}{l}6.0 \\
6.1 \\
6.2 \\
6.3 \\
6.4\end{array}$ & $\begin{array}{r}9.68 \\
9.89 \\
10.11 \\
10.37 \\
10.60\end{array}$ & $\begin{array}{l}9.0 \\
9.1 \\
9.2 \\
9.3 \\
9.4\end{array}$ & $\begin{array}{l}17.80 \\
18.18 \\
18.50 \\
18.85 \\
19.20\end{array}$ & & \\
\hline
\end{tabular}

Example: Suppose the standard preparation containing 1 international unit of male hormone (the equivalent of 100 gamma androsterone) per cc. gave an $\mathrm{L}+\mathrm{H}$ value of 4.7 and your unknown, after correction to the same average initial comb-length as your standard used in parallel, gave an $\mathrm{L}+\mathrm{H}$ value of 4.0. Then, since the equivalents in terms of $0.001 \mathrm{cc}$. $\theta \mathrm{SH}$ are 6.8 and 5.31 respectively, it follows that the unknown contains $5.31 / 6.8$ or 0.78 international male hormone unit per cc.

excretion of androgens is very striking, ranging from 13 to 69 international units per day. In only one of the men, Subject 1 , is there a suggestion of a cycle. In spite of these irregularities, the average daily excretion for the four men is remarkably constant, ranging from 38 to 41 international units. It should be noted that these values were obtained after 2 hours' acid hydrolysis of the urine at boiling temperature. Undoubtedly, all these values would have been appreciably higher by our latest modification of hydrolysis 
(17). If, on the basis of other observations, we assume that 15-minute acid hydrolysis at boiling temperature before extraction would have increased the yield of androgenic activity by 66 per cent over the 2 -hour boiling, the average values would be 63 to 69 international androgenic units, or the equivalent of 6.3 to $6.9 \mathrm{mgm}$. of androsterone per day.

The daily excretion of estrogenic material, expressed as theelin, varies from 2 to 29 gamma in the entire male group and even in one individual.
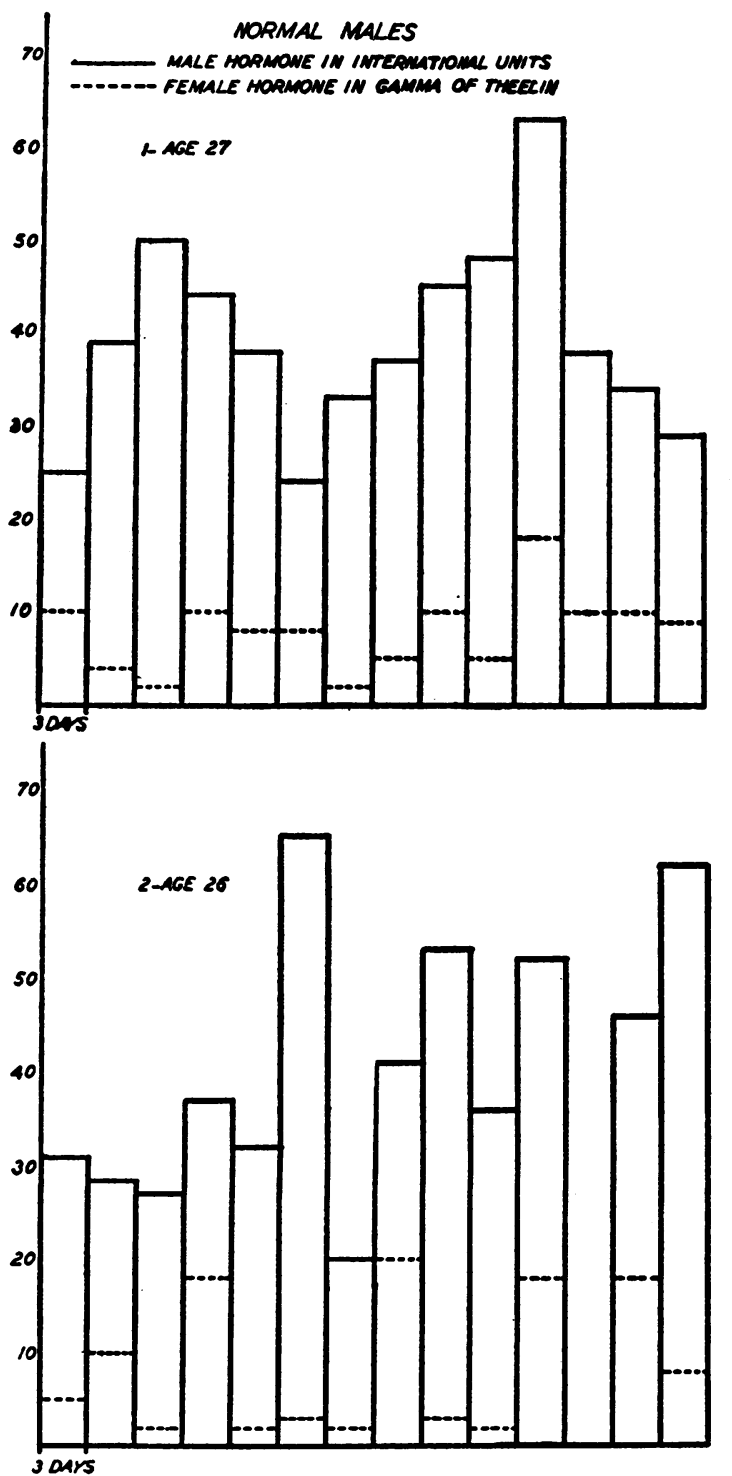

The average theelin values range from 9 to 12 gamma per day.

The rates of excretion of the androgenic and estrogenic activities bear no relation to each other. This is very well illustrated by the marked variations in the ratios obtained by dividing the androgenic units by the gamma of theelin per day. These are given as An/Es in Table II. However, the average values for the ratio are again remarkably constant, ranging from 3.3 to 4.6 on the 2-hour boiling treatment. If calculated on the
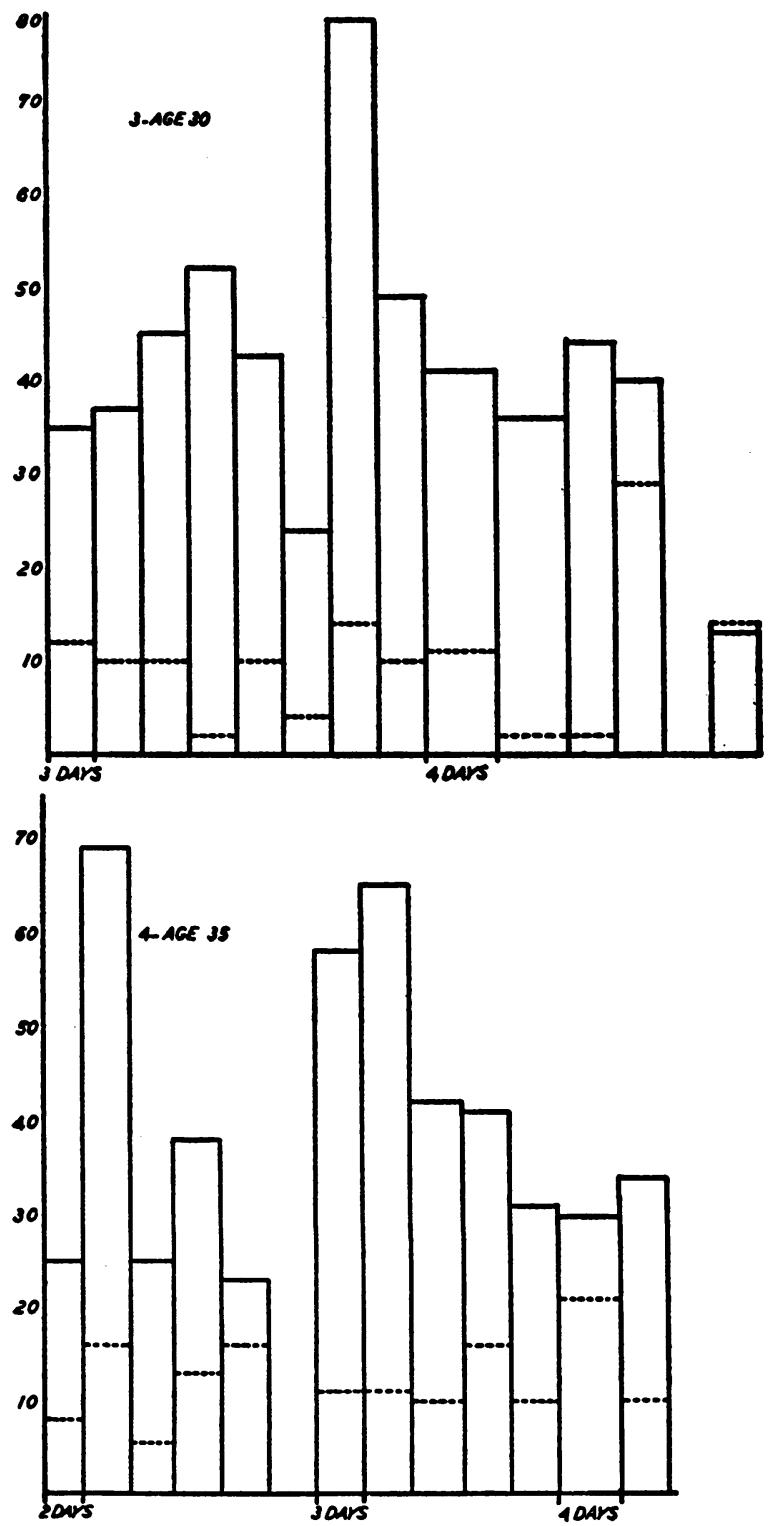

Fig. 2. The Excretion of ANdrogenic and Estrogenic Substances in the Urine of Four Normal Men for Periods of Six WeEks Each 
TABLE II

The daily urinary excretion of androgenic and estrogenic activities by four normal men*

(The urine of these subjects was boiled for 2 hours before extraction)

\begin{tabular}{|c|c|c|c|c|c|c|c|c|c|c|c|c|c|c|c|}
\hline \multicolumn{4}{|c|}{$\begin{array}{l}\text { Subject 1, } \\
\text { age } 27 \text { years }\end{array}$} & \multicolumn{4}{|c|}{$\begin{array}{l}\text { Subject } 2 \text {, } \\
\text { age } 26 \text { years }\end{array}$} & \multicolumn{4}{|c|}{$\begin{array}{l}\text { Subject 3, } \\
\text { age } 30 \text { years }\end{array}$} & \multicolumn{4}{|c|}{$\begin{array}{l}\text { Subject 4, } \\
\text { age } 35 \text { years }\end{array}$} \\
\hline Days & $\mathbf{A n}$ & $E_{6}$ & $\frac{A_{n}}{E_{s}}$ & Days & An & $\mathrm{E}_{\mathbf{B}}$ & $\frac{\mathrm{An}_{\mathrm{n}}}{\mathrm{E}_{\mathrm{B}}}$ & Deys & An & $\mathrm{Ea}$ & $\frac{A_{n}}{E_{B}}$ & Days & $\mathbf{A n}$ & $E_{B}$ & $\frac{\mathrm{An}}{\mathrm{E}_{\mathrm{s}}}$ \\
\hline $\begin{array}{l}\mathbf{8} \\
\mathbf{8} \\
\mathbf{3} \\
\mathbf{3} \\
\mathbf{3} \\
\mathbf{3} \\
\mathbf{3} \\
\mathbf{3} \\
\mathbf{3} \\
\mathbf{8} \\
\mathbf{8} \\
\mathbf{3} \\
\mathbf{3} \\
\mathbf{3}\end{array}$ & $\begin{array}{l}25 \\
39 \\
50 \\
34 \\
38 \\
24 \\
33 \\
37 \\
45 \\
48 \\
63 \\
38 \\
34 \\
29\end{array}$ & $\begin{array}{r}10 \\
8 \\
4 \\
10 \\
8 \\
8 \\
5 \\
5 \\
5 \\
10 \\
5 \\
18 \\
10 \\
10 \\
9\end{array}$ & $\begin{array}{r}3 \\
5 \\
12 \\
3 \\
5 \\
3 \\
7 \\
8 \\
5 \\
5 \\
10 \\
4 \\
4 \\
3 \\
3\end{array}$ & $\begin{array}{l}\mathbf{3} \\
\mathbf{3} \\
\mathbf{3} \\
\mathbf{3} \\
\mathbf{3} \\
\mathbf{3} \\
\mathbf{3} \\
\mathbf{3} \\
\mathbf{3} \\
\mathbf{3} \\
\mathbf{3} \\
\mathbf{3} \\
\mathbf{3} \\
\mathbf{3} \\
\mathbf{3}\end{array}$ & $\begin{array}{l}40 \\
28 \\
27 \\
37 \\
32 \\
65 \\
20 \\
41 \\
53 \\
36 \\
52 \\
108 t \\
46 \\
62\end{array}$ & \begin{tabular}{|r|}
5 \\
10 \\
2 \\
18 \\
2 \\
3 \\
2 \\
20 \\
3 \\
2 \\
18 \\
18 \\
8
\end{tabular} & \begin{tabular}{|r|}
8 \\
3 \\
14 \\
2 \\
16 \\
22 \\
10 \\
2 \\
18 \\
18 \\
3 \\
\\
3 \\
8
\end{tabular} & $\begin{array}{l}\mathbf{3} \\
\mathbf{3} \\
\mathbf{3} \\
\mathbf{3} \\
\mathbf{3} \\
\mathbf{3} \\
\mathbf{3} \\
\mathbf{3} \\
\mathbf{4} \\
\mathbf{4} \\
\mathbf{3} \\
\mathbf{3} \\
\mathbf{3} \\
\mathbf{3}\end{array}$ & $\begin{array}{c}30 \\
37 \\
45 \\
52 \\
42 \\
24 \\
79 \\
49 \\
41 \\
36 \\
44 \\
40 \\
\text { lost } \\
13\end{array}$ & \begin{tabular}{|r}
12 \\
10 \\
10 \\
26 \\
10 \\
4 \\
14 \\
10 \\
11 \\
2 \\
2 \\
29 \\
14
\end{tabular} & $\begin{array}{r}3 \\
4 \\
5 \\
2 \\
4 \\
6 \\
6 \\
5 \\
4 \\
18 \\
22 \\
1\end{array}$ & $\begin{array}{l}2 \\
3 \\
3 \\
3 \\
3 \\
3 \\
3 \\
3 \\
3 \\
3 \\
3 \\
4 \\
4 \\
3\end{array}$ & $\begin{array}{l}25 \\
69 \\
25 \\
38 \\
23 \\
58 \\
65 \\
42 \\
41 \\
31 \\
30 \\
34\end{array}$ & \begin{tabular}{|c}
8 \\
16 \\
5 \\
13 \\
16 \\
11 \\
11 \\
10 \\
16 \\
10 \\
21 \\
10
\end{tabular} & $\begin{array}{l}3 \\
4 \\
5 \\
\mathbf{3} \\
2 \\
5 \\
6 \\
4 \\
\mathbf{4} \\
\mathbf{3} \\
\mathbf{2} \\
\mathbf{3}\end{array}$ \\
\hline $\begin{array}{l}\text { Average } \\
\text { values }\end{array}$ & 38 & 9 & 4.2 & & 41 & 9 & 4.6 & & 41 & 10 & 4.1 & & 40 & 12 & 3.3 \\
\hline
\end{tabular}

* "An" designates international androgenic units per day. "Es" designates estrogenic activity as gamma of theelin per day.

basis of the 15-minute boiling process, these ratios are raised to range from 5.5 to 7.6 (Table IV).

Women's urine. The results on the four women are given in Figure 3 and Table III. The urines from Subjects 1, 2 and 3 were hydrolyzed by the 2 -hour process, but in the case of Subject 4 the more reliable 15 -minute boiling procedure was used. The increase in yield of androgens by the 15-minute process in Subject 4 as compared with the longer period of hydrolysis in Subjects 1,2 and 3 is very striking and is confirmed by control experiments on many other studies on women's urine. In Subjects 1, 2 and 3, the androgenic units excreted per day range from 13 to 46 and again the same range holds for one individual. In Subject 4 the excretion is more constant, ranging from 42 to 85 . The average values for the women are again very constant if calculated on the same basis (Table IV). They are, however, distinctly lower than the averages for men. A more extended series will be necessary for the perfectly satisfactory establishment of this sexual difference.

The daily excretion of estrogenic material expressed as theelin in the women ranges from 4 to 60 gamma. The average daily excretion on the four subjects varied from 18 to 27 gamma of theelin. Figure 2 shows that, although our estro- genic assays may not have been as accurate as desired, there is a suggestion of two peaks during the cycle, one at 7 to 15 days after the onset of menstruation, and one at 6 to 12 days before the onset of the next menstrual period. In each case the excretion rate is lowest during menstruation. Our findings thus confirm the results reported by Gustavson and Green (13) and Frank (12). The significance of the peaks in the excretion of estrogens in women cannot be fully analyzed at the present time because of our incomplete knowledge on the changes in concentration of estrogens in blood and the relation thereof to ovarian-follicle and corpus-luteum formation and degeneration.

In women as in men the rates of excretion of androgenic and estrogenic substances in the urine bear no relation to each other. From Tables III and IV it is seen that the An/Es ratio is lower in women than in men. By the 2-hour boiling procedure this ratio ranges from 0.3 to 7 , whereas in men it varied from 1 to 22 . The average values of the ratio for these normal women ranges from 1.2 to 2.8 and 0.72 to 1.7 for the 15 -minute and 2-hour boiling procedures respectively.

The source of these urinary hormones is, of course, of interest when we consider that both sexes excrete both types. Although it is defi-

TABLE III

The daily urinary excretion of androgenic and estrogenic activities by four normal women*

(The urine of Subject 4 was hydrolyzed for 15 minutes, the others for 2 hours)

\begin{tabular}{|c|c|c|c|c|c|c|c|c|c|c|c|c|c|c|c|}
\hline \multicolumn{4}{|c|}{$\begin{array}{l}\text { Subject 1, } \\
\text { age } 34 \text { years }\end{array}$} & \multicolumn{4}{|c|}{$\begin{array}{c}\text { Subject 2, } \\
\text { age } 31 \text { years }\end{array}$} & \multicolumn{4}{|c|}{$\begin{array}{l}\text { Subject 3, } \\
\text { age } 24 \text { years }\end{array}$} & \multicolumn{4}{|c|}{$\begin{array}{c}\text { Subject 4, } \\
\text { age } 23 \text { years }\end{array}$} \\
\hline Days & An & Es & $\frac{A n}{E_{3}}$ & Days & $\mathbf{A n}$ & $\mathrm{Es}$ & $\frac{\mathrm{An}}{\mathrm{E}}$ & Days & An & Es & $\frac{\text { An }}{E_{s}}$ & Days & An & Es & $\frac{A n}{E_{B}}$ \\
\hline $\begin{array}{l}\mathbf{5} \\
\mathbf{2} \\
\mathbf{2} \\
\mathbf{2} \\
\mathbf{2} \\
\mathbf{2} \\
\mathbf{2} \\
\mathbf{2} \\
\mathbf{2} \\
\mathbf{2} \\
\mathbf{2} \\
\mathbf{2}\end{array}$ & $\begin{array}{l}22 \\
42 \\
21 \\
31 \\
29 \\
23 \\
19 \\
20 \\
22 \\
17 \\
108 t \\
25\end{array}$ & $\begin{array}{l}7 \\
31 \\
25 \\
28 \\
18 \\
21 \\
40 \\
35 \\
30 \\
34 \\
30\end{array}$ & $\begin{array}{l}3 \\
1 \\
1 \\
1 \\
2 \\
1 \\
0.5 \\
0.5 \\
0.5 \\
0.5 \\
1.0\end{array}$ & $\begin{array}{l}\mathbf{3} \\
\mathbf{2} \\
\mathbf{2} \\
\mathbf{2} \\
\mathbf{2} \\
\mathbf{2} \\
\mathbf{2} \\
\mathbf{2} \\
\mathbf{2} \\
\mathbf{2} \\
\mathbf{2} \\
\mathbf{7}\end{array}$ & $\begin{array}{l}20 \\
35 \\
30 \\
18 \\
27 \\
27 \\
26 \\
28 \\
25 \\
26 \\
18 \\
26\end{array}$ & $\begin{array}{l}44 \\
38 \\
22 \\
53 \\
30 \\
30 \\
60 \\
40 \\
40 \\
40 \\
18 \\
13\end{array}$ & $\begin{array}{l}0.5 \\
1.0 \\
1 \\
0.5 \\
1.0 \\
1.0 \\
0.5 \\
0.5 \\
0.5 \\
0.5 \\
1 \\
2\end{array}$ & $\begin{array}{l}\mathbf{2} \\
\mathbf{2} \\
\mathbf{2} \\
\mathbf{2} \\
\mathbf{2} \\
\mathbf{2} \\
\mathbf{2} \\
\mathbf{2} \\
\mathbf{2} \\
\mathbf{2} \\
\mathbf{2} \\
\mathbf{2} \\
\mathbf{2} \\
\mathbf{2} \\
\mathbf{2}\end{array}$ & $\begin{array}{l}22 \\
13 \\
28 \\
36 \\
19 \\
22 \\
42 \\
16 \\
46 \\
108 \\
23 \\
36 \\
29 \\
20 \\
24\end{array}$ & $\begin{array}{r}5 \\
5 \\
10 \\
21 \\
9 \\
25 \\
21 \\
16 \\
22 \\
27 \\
18 \\
28 \\
10 \\
22\end{array}$ & $\begin{array}{l}\mathbf{4} \\
\mathbf{3} \\
\mathbf{3} \\
\mathbf{2} \\
\mathbf{2} \\
\mathbf{1} \\
\mathbf{2} \\
\mathbf{1} \\
\mathbf{2} \\
\mathbf{1} \\
\mathbf{2} \\
\mathbf{1} \\
\mathbf{2} \\
1\end{array}$ & $\begin{array}{l}2 \\
5 \\
2 \\
2 \\
2 \\
2 \\
2 \\
2 \\
2 \\
2 \\
2 \\
2 \\
2 \\
2 \\
2 \\
2\end{array}$ & $\begin{array}{l}70 \\
45 \\
45 \\
45 \\
42 \\
40 \\
100 t \\
50 \\
53 \\
60 \\
68 \\
56 \\
85 \\
68\end{array}$ & $\begin{array}{r}21 \\
4 \\
8 \\
8 \\
11 \\
28 \\
25 \\
16 \\
16 \\
41 \\
32 \\
28 \\
24\end{array}$ & $\begin{array}{r}3 \\
11 \\
6 \\
6 \\
4 \\
2 \\
\\
2 \\
3 \\
4 \\
2 \\
2 \\
3 \\
3\end{array}$ \\
\hline $\begin{array}{l}\text { Average } \\
\text { values }\end{array}$ & 25 & 27 & 0.85 & & 26 & 36 & 0.72 & & 28 & 18 & 1.6 & & 56 & 20 & 2.8 \\
\hline
\end{tabular}

* "An" designates international androgenic units per day. "Es" designates estrogenic activity as gamma of theelin per day. 

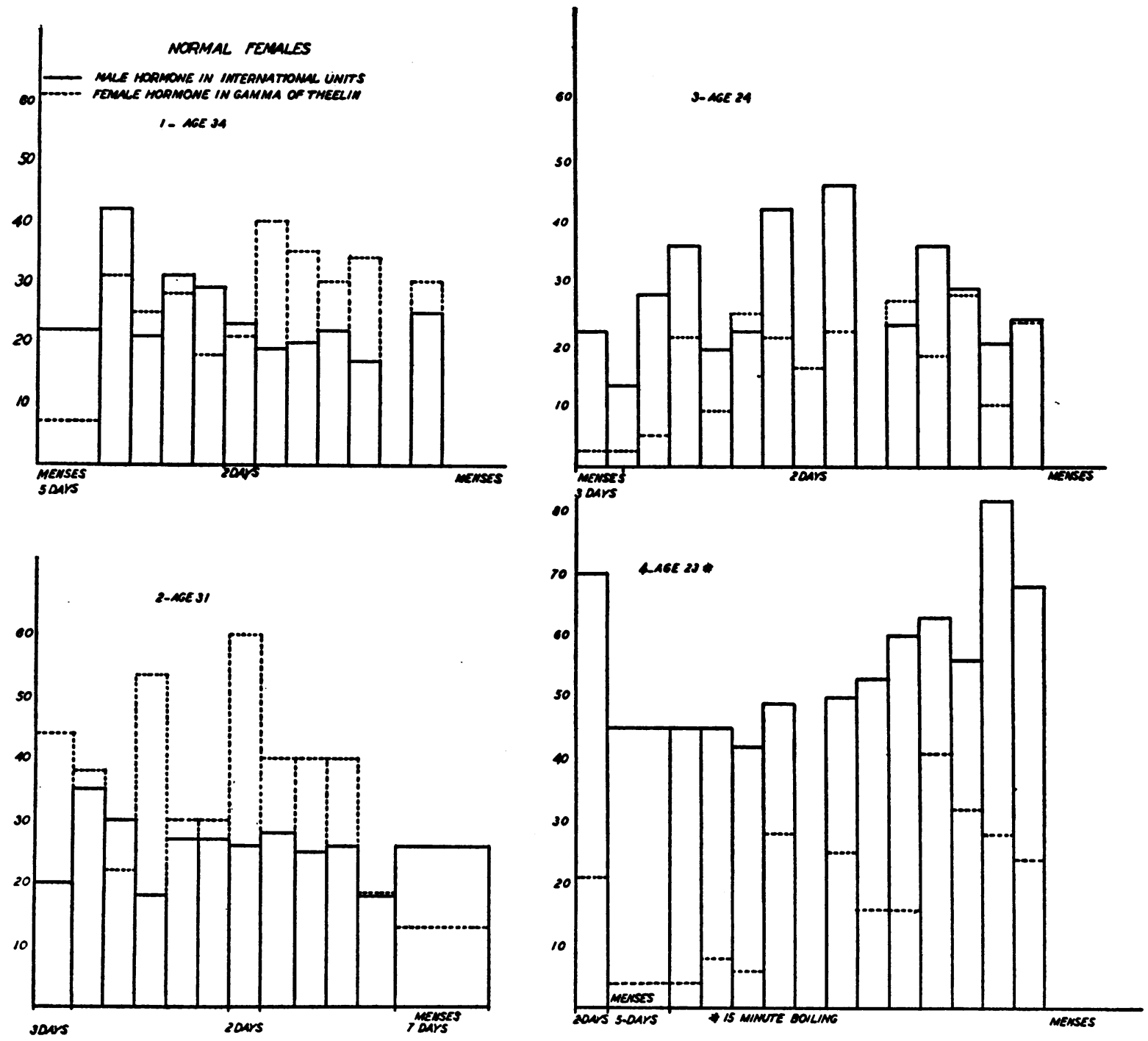

Fig. 3. The Excretion of Androgenic and Estrogenic Substances in the Urine of Four Normal Women throughout the Menstrual Cycle

nitely established that hormone concentrates from testis tissue contain estrogenic material, the evidence for androgenic material in ovarian extracts is not so well established. Nevertheless, there is considerable evidence that comb-growth in the hen or pullet is due to an androgenic substance and that this probably comes from the ovarian medulla (19). Pure estrogenic substances do not cause comb-growth in the hen but pure androgens do. It is also possible that a number of androgenic and estrogenic materials may be formed in the metabolism of hypothetical common precursors for androgens and estrogens. This may in- volve not only the normal or abnormal processes in the gonads, but also normal or pathological metabolism of sterols or other intermediates in the suprarenals and liver. That the suprarenal may be involved is suggested by the findings of Frank (20) and the authors (21) as well as by the oxidative degradation studies on one of the crystalline compounds isolated from the adrenal cortex $(22,23)$. To what extent our food contains sex hormones or precursors easily metabolized to active waste products remains to be seen. However, this source is not a very significant one directly, because castrates excrete only very small 
TABLE IV

$A$ summary of the average values from Tables $I I$ and $I I I^{*}$

\begin{tabular}{|c|c|c|c|c|c|c|c|c|c|c|c|}
\hline \multicolumn{6}{|c|}{ Men } & \multicolumn{6}{|c|}{ Women } \\
\hline Subject & An's & An ${ }^{120}$ & Es & $\frac{\mathrm{An}^{16}}{\mathrm{Es}}$ & $\frac{A^{12 x}}{E_{s}}$ & $\begin{array}{c}\text { Sub- } \\
\text { ject }\end{array}$ & $\mathrm{An}^{15}$ & An ${ }^{120}$ & Es & $\frac{\mathrm{An}^{15}}{\mathrm{E}_{8}}$ & $\frac{A^{100}}{E_{8}}$ \\
\hline $\begin{array}{l}1 \\
2 \\
3 \\
4\end{array}$ & $\begin{array}{l}63 t \\
68 t \\
68 t \\
66 t\end{array}$ & $\begin{array}{l}38 \\
41 \\
41 \\
40\end{array}$ & $\begin{array}{r}9 \\
9 \\
10 \\
12\end{array}$ & $\begin{array}{l}7.0 \\
7.6 \\
6.8 \\
5.5\end{array}$ & $\begin{array}{l}4.2 \\
4.6 \\
4.1 \\
3.3\end{array}$ & $\begin{array}{l}1 \\
2 \\
3 \\
4\end{array}$ & $\begin{array}{l}42 \dagger \\
43 \dagger \\
47 \dagger \\
56\end{array}$ & $\begin{array}{l}25 \\
26 \\
28 \\
34 \dagger\end{array}$ & $\begin{array}{l}27 \\
36 \\
18 \\
20\end{array}$ & $\begin{array}{l}1.6 \\
1.2 \\
2.5 \\
2.8\end{array}$ & $\begin{array}{l}0.9 \\
0.7 \\
1.5 \\
1.7\end{array}$ \\
\hline \multicolumn{2}{|c|}{ Average } & & & 6.9 & 4.1 & & & & & 2.0 & 1.2 \\
\hline
\end{tabular}

* " $\mathrm{An}^{15}$ " designates the international androgenic units per day by the 15-minute boiling procedure.

"An120" the same by the 2-hour boiling-procedure.

"Es" designates the estrogenic activity as gamma of theelin per day.

† These values are calculated on the assumption that the yield of androgenic activity is increased by 66 per cent over the 2-hour hydrolysis if boiled 15 minutes instead.

amounts of these hormones. Even if foods did contain small amounts of these substances, their incomplete absorption probably would eliminate this factor as a significant source.

The fluctuations in the urinary excretion of these hormones in normal men and women should serve as a warning to all of us not to place too much emphasis on the assays of one or two 24hour samples from one individual.

\section{SUM M ARY}

1. A quantitative method for the extraction of androgenic and estrogenic materials from urine is given in detail.

2. This method has been applied on the urines of four normal men and four normal women over a continuous period of 39 to 45 days for the men and over a complete menstrual cycle for the women.

3. There are marked fluctuations in the daily urinary excretion of androgens and estrogens in normal men and women.

4. There is no definite evidence of a monthly cycle in the excretion of either androgens or estrogens in normal men. In normal women the excretion of estrogens is characteristically low during the menstrual flow and rises during the intermenstruum with a double peak in certain instances.

5. The average daily excretions of androgens obtained by our best methods of hydrolysis and extraction are 63 to 68 units for the men studied and 42 to 56 units for the women studied, calculated as international androgen units. Our women, therefore, excreted two-thirds as much androgenic material as our men. An extended series is desirable to establish further such a difference between the sexes.

6. The average daily excretions of estrogens, calculated as gammas of theelin, are 9 to 12 gammas for men and 18 to 36 gammas for women.

7. The rates of excretion of androgenic and estrogenic substances do not seem to bear any relation to each other in either sex.

8. On the basis of the best known methods of hydrolysis and extraction, the ratios obtained by dividing the international androgenic units excreted per day by the gammas of theelin excreted per day vary considerably for the same individual. The average values for the eight subjects ranged from 5.5 to 7.6 for men and 1.2 to 2.8 for women.

\section{ADDENDUM}

Since this paper was written an important contribution by Dingemanse, Borchardt and Laqueur (24) has appeared in which the usual male hormone values for the urine of normal men up to the age of 40 are given as 40 to 50 international units per liter. Aged men excreted from 5 to 40 units per liter. These workers differ from us in obtaining no essential difference between men and women. A one and one-half month study of one normal man gives no evidence of cycle, in agreement with our own observations. In one normal woman studied through a cycle there was a slight rise in the excretion of androgenic substances post-menstrually. Small amounts of androgenic material were found consistently in the urine of children.

\section{BIBLIOGRAPHY}

1. Butenandt, A., and Tscherning, K., Utber Androsteron ein krystallisiertes männliches Sexualhormon. I. Isolierung und Reendarstellung aus Männerharn. Ztschr. f. physiol. Chem., 1934, 229, 167.

Ibid. II. Seine chemische Charakterisierung. Ibid., p. 185.

2. Butenandt, A., and Dannenbaum, H., Ibid. III. Isolierung eines neuen, physiologisch unwirksamen Sterinderivates aus Männerharn, seine Verknüpfung mit Dehydro-androsteron und Androsteron: ein Beitrag zur Konstitution des Androsterons. Ztschr. f. physiol. Chem., 1934, 229, 192.

3. Butenandt, A., Dannenbaum, H., Hanisch, G., and 
Kudszus, Helmut, Uber Dehydroandrosteron. Ztschr. f. physiol. Chem., 1935, 237, 57.

4. Dorfman, R. I., Gallagher, T. F., and Koch, F. C., The nature of the estrogenic substance in human male urine and bull testis. Endocrinology, 1935, 19, 33.

5. Funk, C., and Harrow, B., The male hormone. Proc. Soc. Exper. Biol. and Med., 1929, 26, 325.

6. Siebke, H., Ergebnisse von Mengenbestimmungen des Sexualhormons. II. Sexualhormon im Harn bei regelmässigem mensuellem Zyklus. Zentrbl. f. Gynäk., 1930, 54, 1601.

Siebke, H., and Schuschania, P., Ibid. IV. Sexualhormon im Harn und Kot bei regelmassigem mensuellem Zyklus, Zyklusstörungen und bei Hormontherapie. Ibid., p. 1734.

7. Ogata, Akira, and Ito, Yasoji, The hormone in the urine of males. J. Pharm. Soc. Jap., 1932, 52, 674 (79-91 in German).

8. Bühler, F., Sexualhormonbefunde im Harn von Männern verschiedenen Alters. Ztschr. f. d. ges. exper. Med., 1933, 86, 650.

9. Simpson, S. L., de Fremery, P., and Macbeth, A., The presence of an excess of male (comb growth and prostate stimulating) hormone in virilism and pseudohermaphroditism. Endocrinology, 1936, 20, 363.

10. Kochakian, C. D., Excretion of male hormones. I. Endocrinology, 1937, 21, 60.

11. Siebke, $H$., Thelykinin und Androkinin, das weibliche und männliche Sexualhormon, im Körper der Frau. Arch. f. Gynäk., 1931, 146, 417.

12. Frank, R. T., The rôle of the female sex hormone. J. A. M. A., 1931, 97, 1852.

13. Gustavson, R. G., and Green, D. F., The quantitative determination of the amount of estrogenic substances excreted daily in the urine of the normal human female. J. Biol. Chem. (Proc.), 1934, 105, xxxiv.

14. Smith, G. V. S., and Smith, O. W., The quantitative determination of urinary oestrin. Am. J. Physiol., $1935,112,340$.
15. Gallagher, T. F., Koch, F. C., and Dorfman, R. I., Procedure for quantitative extraction of sex hormones from urine. Proc. Soc. Exper. Biol. and Med., 1935, 33, 440.

16. Gallagher, T. F., and Koch, F. C., The quantitative assay for the testicular hormone by the combgrowth reaction. Second communication. J. Pharmacol. and Exper. Therap., 1935, 55, 97.

17. Peterson, D. H., Gallagher, T. F., and Koch, F. C., The effect of acid hydrolysis on the yield of androgenic and estrogenic activities from human urine. J. Biol. Chem., 1937, 119, 185.

18. D'Amour, F. E., and Gustavson, R. G., A critical study of the assay of female sex hormone preparations. J. Pharmacol. and Exper. Therap., 1930, 40, 473.

19. Domm, L. V., The effects of daily injections of hebin on the development of sexual characters in leghorn chicks. Transactions on the Dynamics of Development (Russian), 1935, 10, 67.

20. Frank, R. T., A suggested test for functional cortical adrenal tumor. Proc. Sox. Exper. Biol. and Med., 1934, 31, 1204.

21. Kenyon, A. T., Gallagher, T. F., Peterson, D. H., Dorfman, R. I., and Koch, F. C., The urinary excretion of androgenic and estrogenic substances in certain endocrine states. Studies in hypogonadism, gynecomastia and virilism. J. Clin. Invest., 1937, 16, 705.

22. Kendall, E. C., Mason, H. L., and Myers, C. S., Concerning the chemical nature of the hormone of the adrenal cortex. Proc. Staff Meet. Mayo Clin., 1936, 11, 351.

23. Reichstein, T., Adrenosterone. Über die Bestandteile der Nebennierenrinde. II. Helv. Chim. Acta, 1936, 19, 223.

24. Dingemanse, E., Borchardt, H., and Laqueur, E., Capon comb growth-promoting substances ("male hormones") in human urine of males and females of varying age. Biochem. J., 1937, 36, 500. 